\title{
THE HETEROGENEOUS EFFECT OF EDUCATIONAL ATTAINMENT ON THE CRIME RATE: MICRO EVIDENCE FROM UNION COUNCIL LEVEL DATA
}

\author{
Waqar Ahmad \\ PhD Rural Sociology, Lecturer, Department of Sociology, \\ University of Swabi. \\ waqaryousafzai99@gmail.com \\ Javed Iqbal \\ Assistant Professor, IMSciences, Peshawar. \\ javed.iqbal@imsciences.edu.pk \\ Zafar Habib \\ Assistant Professor, IMSciences, Peshawar. \\ zafar.habib@imsciences.edu.pk
}

\begin{abstract}
Crime seems to be firmly related to the level of education. The objective of this study is to investigate the effect of educational attainment (independent variable) on crime rate (dependent variable) at a local level of union council. Data on 376 individuals have been worked through uni-variate and bivariate analysis. The sample has been drawn through stratified random sampling to make sure valid illustration representing all strata at the union council. At a uni-variate level, it has alluded that lack of religious knowledge amplifies the crime rate, however youth gangs, an open business of drugs, weapons display, and physical fights are significant manifestations of illiteracy. Lack of awareness regarding crime, lack of formal and informal education, absence of implementation of true law and order are considered to be additional factors in the intensification of the crime rate. At bi-variate level, the study further assesses that youth gangsters, lack of awareness regarding crime, and lack of formal and informal education have been found highly significant associated ( $p=0.000)$, while lack of religious knowledge was found significant $(p=0.006)$ with crime in society. The notable conclusion of the study is that youth gangsters, lack of awareness, lack of formal and informal education, poor socialization of children, and absence of law and order situation are contributing factors towards amplification of crime at societal levels. In the light of the conclusion, the study recommends that a uniform system of education should be introduced to create avenues for a tolerant and peace-abiding society. Furthermore, government and non-governmental organizations should introduce various economic (microfinance schemes), social (behavior change programs), and political programs (right to assembly, rule of law, right to demand services) particularly aimed at youth and poor segments of the society.
\end{abstract}

Keyword: Heterogeneous effect, educational attainment, crime in Society, crime rate.

\section{INTRODUCTION}

Criminality originates from the Latin word "Crimen" which is presented as a social issue, and can't be ruled out from the life of the individual (Gillani, Rehman, \& Gill, 2009). Crimes constantly has created distress in societies around the world, and has resulted in emotional insecurity and timidity amongst People (Khan, Ahmed, Nawaz, \& Zaman, 2015). A drop in crime rate could be attained by more prevention and regulation. What different studies tells us is that education is intuitively significant component to avert people from criminal conduct. Though criminality tended to be higher in those areas where people had a low level of education, and the additional cause for more permissive attitudes and social norms towards the criminal behavior might be that people having a higher level of education have a more liberal world view in general (Groot \& van den Brink, 2010). Additionally, education may also teach people to be more lenient and patient (Becker \& Mulligan, 1997). However, Bell, Costa, and Machin (2016) accentuated the prerequisite for a deeper consideration of diverse effects inside the criminal tendencies dropping effects of the attainment of 
education. Additionally, the Council of Economic Advisers (2016) determined that amongst additional factors, investing in the educational sector could be the most cost-effective in the decline of crime ratio than incarceration. Lack of education has a higher impact on the crime ratio committed in the younger ages as well (Hjalmarsson, Holmlund, \& Lindquist, 2015). It had been alluded to by Rahman and Uddin (2009) that education is considered to be the vital need of all beings and a pivotal gauge of any country's development. Education is the effort of any state, who would ensure everything in their means, in the sphere of available resources, and to provide the funds and facilities to boost up their standard. While on the other end, the community had also a key role in the progress of educational entities. Particularly, Pakistan had the highest concentration of illiterates across the region. According to the United Nations Educational Scientific and Cultural Organization (UNESCO), Pakistan at 55\% had one of the lowest literacy rates across the globe and stands on the 160th amongst the world nations. The literacy rate of Khyber Pakhtunkhwa was $15.50 \%$ and $35.40 \%$ in 1972 and 1998, which was improved in the years of 2012, 2013, and 2014 i.e. 60\%, 52\%, and 53\%, while recently have $50 \%$ as well (Rehman, Jingdong, \& Hussain, 2015).

\section{REVIEW OF LITERATURE}

Numerous economists and criminologists have flagged that unfair distribution of resources tempts individuals to embrace criminal behavior (Brush, 2007). Economic depression has been linked to crime and economic prosperity dubbed as a key factor for decline in crime ratio (Dritsakis \& Gkanas, 2009). Educational attainment can diminish crime ratio through its impact on employment and labour productivity (Lochner, 2011). Campaniello, Gray, and Mastrobuoni (2016) provides evidence that effect of income made by educational attainment might intensify the crime ratio by producing elevated returns to unlawful activities compared to legal earnings. Some individuals assume criminal behaviors when they compare financial gains from criminal activities with that of legal work (Becker, 1968). Although, (Ehrlich, 1973) protracted Becker's study by integrating income level and distribution effect, and asserted that unemployment is the pivotal determinant of the crime rates

There is evidence that young people in paid employment or those attending schools are less likely to be involved in criminal activity (Tauchen \& Witte, 1994; Witte \& Tauchen, 1993). Similarly, employment census data of the US shows that schooling ominously diminishes the crime rate. (Lochner \& Moretti, 2004). There is empirical evidence from Argentina that between 1990 to 1999 where income inequality and unemployment had a significant and positive association with the rate of criminal tendencies (Cerro \& Meloni, 2000). While latest research finds that education could be able to shrink the rate of crimes by diverse channels like it has incapacitated impact on the crime ratio, particularly juvenile crime (Nguyen, 2019).

There are studies that suggest that education outcomes doesn't affect crime rates such as one carried out in twenty Italian counties from 1980-1995 (Buonanno, 2003). By using randomized school admittance lotteries, Cullen, Jacob, and Levitt (2006) and Deming (2011) found that those students who 'win' a chance to join superior performance public schools do not essentially perform better in their academics, nevertheless they commit ominously fewer crime throughout school time, particularly in the primary years. Juvenile delinquency meaningfully diminishes the chance of high school and college graduation as well (Ward \& Williams, 2015). Webbink, Koning, Vujić, and Martin (2013) scrutinized the inverse affiliation between crime and education and determined that education can diminish crime rates. By taking gender into consideration, it had been validated that dropout effect and criminal tendencies caused by male education is stronger than that caused by female education. Summarily, the literature has sufficient evidence to suggest that primary level of education seems to have no effect on the level of crime, while higher education, particularly education at secondary level and above, significantly leads to less criminal tendencies (Nguyen, 2019).

\section{MATERIALS AND METHODS}

Union council Kalukhan in Tehsil Razzar, District Swabi was taken as the universe of the study. Though, data was collected from the mentioned union council comprised of five village councils purposively selected; Sheraghund, Khatt, Bazid Khel, Munan Khel, and Parra. According to the Census Report (2017) total population of males in the mentioned union council was 20000 approximately, however, the required sample size from the population was 376 taken by the criteria set out by Sekaran (2003) from the population of 20000 male population. Furthermore, the sample 
size was proportionally allocated to each stratum (village council) by using the proportional allocation method, and they were identified through simple random sampling. All of the respondents were male members aged 18 years or above.

Table No. 1 Showing the Distribution of Each Village Household and Relative Sample Size

\begin{tabular}{|l|l|c|c|}
\hline S.No & Name of the village & Household (each village) $(\mathbf{N})$ & Sample size $(\mathbf{n})$ \\
\hline 1 & Sheraghund & 6000 & 112 \\
\hline 2 & Khataa & 4500 & 85 \\
\hline 3 & Bazid Khel & 3000 & 56 \\
\hline 4 & Munan Khel & 3300 & 63 \\
\hline 5 & Perra & 3200 & 60 \\
\hline & Grand Total & $\mathbf{2 0 0 0 0}$ & $\mathbf{3 7 6}$ \\
\hline
\end{tabular}

The study adapted "Likert scale" to know the magnitude of respondent's choices on given set of questions. Each of them was categorized into "Agree, disagree, and uncertain" respectively. In the measurement scales, the "Likert Scale" was adopted for the operationalization and measurement of responses of the independent variable i.e. educational attainment and dependent variable crime in society. Furthermore, indexation was also performed in the study. It is considered to be one of the foremost norms in social research, which is based on raking into two or more items to create the basis for the structuring of indexation (Smith, 1975); and (Nachmias \& Nachmias, 1976). Consequently, the collected data was scrutinized by using a statistical method (Frequency Distribution) over SPSS version 22, along with Bi-variate analysis, which is the dissemination of data in the outcome of crosstabulation of both variables i.e. dependent and independent. The relationship of both mentioned variables was cross-tabulated and stated in the $3 / 3$ table. Additionally, for the determination of the level of association, the Chi-Square test was applied on the data set (Nachmias \& Nachmias, 1976) and (McCall \& Kagan, 1975).

\section{CONCEPTUAL FRAMEWORK}

\begin{tabular}{|c|c|}
\hline Independent variable & Dependent variable \\
\hline Educational attainment & Crime in society \\
\hline
\end{tabular}

\section{RESULTS}

\section{Education level of the respondents}

Demographic characteristics of the sampled respondents i.e. level of education are presented in the below-mentioned table along with the percentage distribution of the sampled respondents. The majority of the sampled respondents i.e. $25.79 \%$ were educated up to $10^{\text {th }}$ grade. While $19.98 \%$ of the sampled respondents qualified as master and above and $16.75 \%$ of them had intermediate level of education. $15.95 \%$ of the sampled respondents were graduates, and $21.54 \%$ of them were illiterate.

Table No. 2 Educational Distribution

\begin{tabular}{|c|c|c|}
\hline Status & Frequency & Percent \\
\hline Illiterate & 81 & 21.54 \\
\hline Metric & 97 & 25.79 \\
\hline Intermediate & 63 & 16.75 \\
\hline Graduate & 60 & 15.95 \\
\hline Master and above & 75 & 19.98 \\
\hline Total & $\mathbf{3 7 6}$ & $\mathbf{1 0 0 . 0}$ \\
\hline
\end{tabular}

\section{Occupation type of the respondents}

Table 3 show the frequency and percentage distribution of the occupation type of the sampled respondents. The majority of the sampled respondents i.e. $31.38 \%$ were government employees. 
While $25 \%$ of them have their own business, $18.08 \%$ of respondents were jobless, and $14.37 \%$, $11.17 \%$ respondents belonged to the labor and farmer class respectively.

Table No. 3 Occupation

\begin{tabular}{|c|c|c|}
\hline Type & Frequency & Percent \\
\hline Govt Employee & 118 & 31.38 \\
\hline Own business & 94 & 25 \\
\hline Farmer & 42 & 11.17 \\
\hline Labor & 54 & 14.37 \\
\hline Jobless & 68 & 18.08 \\
\hline Total & $\mathbf{3 7 6}$ & $\mathbf{1 0 0 . 0}$ \\
\hline
\end{tabular}

\section{Family monthly income of respondents}

Table 4 below shows the frequency and percentage distribution of monthly income of the sampled respondents. It has been revealed that the majority i.e. $31.66 \%$ of the respondents reported that their family income ranged between 30000 to 40000 PKR per month. $26.86 \%$ of them declared their range of monthly income from 20000 to 30000 PKR, and $14.09 \%$ of the sampled respondents described the range of 10000-20000 PKR. 19.15\% families belonged in the range 40000-50000 PKR and family income of $8.24 \%$ was 50000 PKR or above.

Table No. 4 Family Monthly Income

\begin{tabular}{|c|c|c|}
\hline Income (PKR) & Frequency & Percentage \% \\
\hline $10000-20000$ & 53 & 14.09 \\
\hline $20000-30000$ & 101 & 26.86 \\
\hline $30000-40000$ & 119 & 31.66 \\
\hline $40000-50000$ & 72 & 19.15 \\
\hline 50000 and above & 31 & 8.24 \\
\hline Total & $\mathbf{3 7 6}$ & $\mathbf{1 0 0 . 0}$ \\
\hline
\end{tabular}

\section{Educational Attainment}

The perception of the sampled respondents towards educational attainment and the crime rate has been revealed in table 5 below. Half of the sampled respondents i.e. $188(50.0 \%)$ negated the statement that uneducated members of the family are often involved in criminal activities but a large number of respondents i.e. 171(45.5\%) authenticated the statement. Furthermore, more than three fourth of the sampled respondents i.e. 291(77.4\%) credited that lack of religious knowledge leads to criminal tendencies in the region. However, about two-thirds of respondents i.e. 242(64.4\%) specified that youth gangsters are the causative factors of illiteracy in the study area. Similarly, the majority of the sample population i.e. 275(73.1\%) believed that weapons demonstration and physical fights are the contributing factors of illiteracy. Open use and sale of drugs had been chosen by majority i.e. $273(72.6 \%)$ of the sampled respondents as a cause of criminal activities. Majority of respondents i.e. $269(71.5 \%)$ divulged that illiteracy leads to gambling and thievery, which was negated by one-fourth of sampled respondents i.e. $99(26.3 \%)$ as well. Moreover, more than two-thirds of the sample size i.e. $257(68.4 \%)$ agreed with the statement that lack of awareness about the crime is a major problem in society. Similarly, majority of the sampled respondents $296(78.7 \%)$ opined that lack of formal and informal education is responsible for escalation of crime rate in the area.

Table No. 5 Opinions

\begin{tabular}{|c|l|c|c|c|c|}
\hline S.No. & \multicolumn{1}{|c|}{ Statement } & Agree & Disagree & Uncertain & Total \\
\hline 1 & $\begin{array}{l}\text { Uneducated members of the family } \\
\text { are often involved in criminal } \\
\text { activities }\end{array}$ & $171(45.5 \%)$ & $188(50.0 \%)$ & $17(4.5 \%)$ & $376(100)$ \\
\hline
\end{tabular}


The Heterogeneous Effect of Educational Attainment on the Crime Rate

\begin{tabular}{|c|l|l|l|l|l|}
\hline 2 & $\begin{array}{l}\text { Lack of religious knowledge leads } \\
\text { to criminal tendencies }\end{array}$ & $291(77.4 \%)$ & $74(19.7 \%)$ & $11(2.9 \%)$ & $376(100)$ \\
\hline 3 & $\begin{array}{l}\text { Youth gangsters are the causative } \\
\text { factors of illiteracy }\end{array}$ & $242(64.4 \%)$ & $78(20.7 \%)$ & $56(14.9 \%)$ & $376(100)$ \\
\hline 4 & $\begin{array}{l}\text { Weapons demonstration and } \\
\text { physical fights are the contributing } \\
\text { factors of illiteracy }\end{array}$ & $275(73.1 \%)$ & $76(20.2 \%)$ & $25(6.6 \%)$ & $376(100)$ \\
\hline 5 & $\begin{array}{l}\text { Open use of drugs and selling are at } \\
\text { peak due to illiteracy }\end{array}$ & $273(72.6 \%)$ & $90(23.9 \%)$ & $13(3.5 \%)$ & $376(100)$ \\
\hline 6 & $\begin{array}{l}\text { Illiteracy leads to gambling and } \\
\text { thievery }\end{array}$ & $269(71.5 \%)$ & $99(26.3 \%)$ & $8(2.1 \%)$ & $376(100)$ \\
\hline 7 & $\begin{array}{l}\text { Lack of awareness about crime is a } \\
\text { major problem in society }\end{array}$ & $257(68.4 \%)$ & $85(22.6 \%)$ & $34(9.0 \%)$ & $376(100)$ \\
\hline 8 & $\begin{array}{l}\text { Lack of formal and informal } \\
\text { education is the responsible factor } \\
\text { in the escalation of crime rate in the } \\
\text { area }\end{array}$ & $296(78.7 \%)$ & $55(14.6 \%)$ & $25(6.7 \%)$ & $376(100)$ \\
\hline
\end{tabular}

\section{Crime in Society}

Table 6 show that attitude of respondents to the state crime in the sampled area. Nearly half of sampled respondents i.e. 177(47.1\%) concluded that aggression is better than negotiation but a large number i.e. 148(39.4\%) of them nullified the statement as well. Similarly, a large number of sampled respondents i.e. 167(44.4\%) opined that people prefer aggression to solve conflicts but 164(43.6\%) of them rejected the statement. Moreover, about two-thirds of respondents 233(62.0\%) believed that people use force against those who do not act upon their decisions. Consequently, the majority of the sample size i.e. 307(81.6\%) agreed with the statement that people beat their siblings at home when they do not behave as they desire. Though, it has been accredited by two-third of the sampled respondents i.e. $254(67.6 \%)$ that aggression is the best way to become prominent in the group. Consistently, two-third of the sample size i.e. 240(63.8\%) professed that people enjoy physical fights in society, the majority of them i.e. 308(81.9\%) labeled that people don't follow rules and regulations because they considered it as secondary. Similarly, the majority of respondents i.e. 317(84.3\%) ascribed that people don't like the interference of others in their daily life activities, though only $45(12.0 \%)$ of them denied the statement.

Table No. 6 Crime in Society

\begin{tabular}{|c|l|c|c|c|c|}
\hline S.No. & \multicolumn{1}{|c|}{ Statement } & Agree & Disagree & Uncertain & Total \\
\hline 1. & $\begin{array}{l}\text { Aggression is better than } \\
\text { negotiation }\end{array}$ & $177(47.1 \%)$ & $148(39.4 \%)$ & $51(13.6 \%)$ & $376(100)$ \\
\hline 2. & $\begin{array}{l}\text { People prefer aggression to solve } \\
\text { conflicts }\end{array}$ & $167(44.4 \%)$ & $164(43.6 \%)$ & $45(12.0 \%)$ & $376(100)$ \\
\hline 3. & $\begin{array}{l}\text { People use force against those who } \\
\text { do not act upon their decisions }\end{array}$ & $233(62.0 \%)$ & $103(27.4 \%)$ & $40(10.6 \%)$ & $376(100)$ \\
\hline 4. & $\begin{array}{l}\text { People beat their siblings at home } \\
\text { when they do not behave as they } \\
\text { desire }\end{array}$ & $307(81.6 \%)$ & $52(13.8 \%)$ & $17(4.5 \%)$ & $376(100)$ \\
\hline 5. & $\begin{array}{l}\text { Aggression is the best way to } \\
\text { become prominent in the group }\end{array}$ & $254(67.6 \%)$ & $103(27.4 \%)$ & $19(5.1 \%)$ & $376(100)$ \\
\hline 6. & $\begin{array}{l}\text { People enjoy physical fights in } \\
\text { society }\end{array}$ & $240(63.8 \%)$ & $115(30.6 \%)$ & $21(5.6 \%)$ & $376(100)$ \\
\hline
\end{tabular}




\begin{tabular}{|c|l|l|l|l|l|}
\hline 7. & $\begin{array}{l}\text { People don't follow rules and } \\
\text { regulations because they } \\
\text { considered it as secondary }\end{array}$ & $308(81.9 \%)$ & $49(13.0 \%)$ & $19(5.1 \%)$ & $376(100)$ \\
\hline 8. & $\begin{array}{l}\text { People don't like interference of } \\
\text { others in their daily life activities }\end{array}$ & $317(84.3 \%)$ & $45(12.0 \%)$ & $14(3.7 \%)$ & $376(100)$ \\
\hline
\end{tabular}

Association between Educational attainment and Crime in Society

At the bi-variate level results signposted a highly significant association $(p=0.000)$ between youth gangsters are the causative factors of illiteracy and crime in society. However, lack of awareness about the crime is a foremost problem that was found highly significant $(\mathrm{p}=0.000)$ with a crime in society. Lack of formal and informal education was determined as highly significant associated $(\mathrm{p}=0.000)$ with a crime in society. Similarly lack of religious knowledge too leads to criminal tendencies as the association found is significant $(p=0.006)$. Results indicate a non-significant association $(p=0.430)$ to the assertion that its only uneducated family members who may often be involved in criminal activities. Likewise, weapon demonstration and physical fights was determined as non-significant $(p=0.173)$ with a crime in society. Similarly, a non-significant $(p=0.245)$ association was found between open use of drugs and selling are at a peak due to illiteracy and crime in society. Lastly illiteracy leads to gambling and thievery and crime in society was found to be nonsignificant $(p=0.107)$ as well.

Table No. 7 Association between Education and Crime in Society

\begin{tabular}{|c|c|c|c|c|c|c|}
\hline \multirow[t]{2}{*}{ Attribute } & \multirow[t]{2}{*}{ Response } & \multicolumn{3}{|c|}{ Crime in society } & \multirow{2}{*}{ Statistics } & \multirow{2}{*}{ Total } \\
\hline & & Agree & Disagree & Uncertain & & \\
\hline \multirow{3}{*}{$\begin{array}{l}\text { Uneducated } \\
\text { members of the } \\
\text { family are often } \\
\text { involved in criminal } \\
\text { activities }\end{array}$} & Agree & $113(48.9 \%)$ & $46(39.0 \%)$ & $12(44.4 \%)$ & \multirow{3}{*}{$\begin{aligned} x^{2} & =3.829 \\
p & =0.430\end{aligned}$} & \multirow{3}{*}{$376(100 \%)$} \\
\hline & Disagree & $108(46.8 \%)$ & $67(56.8 \%)$ & $13(48.1 \%)$ & & \\
\hline & Uncertain & $10(4.3 \%)$ & $5(4.2 \%)$ & $2(7.4 \%)$ & & \\
\hline \multirow{3}{*}{$\begin{array}{l}\text { Lack of religious } \\
\text { knowledge leads to } \\
\text { criminal tendencies }\end{array}$} & Agree & $190(82.3 \%)$ & $82(69.5 \%)$ & $19(70.4 \%)$ & \multirow{3}{*}{$\begin{array}{l}x^{2} \\
=14.633 \\
p=0.006\end{array}$} & \multirow{3}{*}{$376(100 \%)$} \\
\hline & Disagree & $36(15.6 \%)$ & $33(28.0 \%)$ & $5(18.5 \%)$ & & \\
\hline & Uncertain & $5(2.2 \%)$ & $3(2.5 \%)$ & $3(11.1 \%)$ & & \\
\hline \multirow{3}{*}{$\begin{array}{l}\text { Youth gangsters are } \\
\text { the causative factors } \\
\text { of illiteracy }\end{array}$} & Agree & $175(75.8 \%)$ & $50(42.4 \%)$ & $17(63.0 \%)$ & \multirow{3}{*}{$\begin{array}{l}x^{2} \\
=38.313 \\
p=0.000\end{array}$} & \multirow{3}{*}{$376(100 \%)$} \\
\hline & Disagree & $31(13.4 \%)$ & $41(34.7 \%)$ & $6(22.2 \%)$ & & \\
\hline & Uncertain & $25(10.8 \%)$ & $27(22.9 \%)$ & $4(14.8 \%)$ & & \\
\hline \multirow{3}{*}{$\begin{array}{l}\text { Weapon } \\
\text { demonstration and } \\
\text { physical fights are } \\
\text { the contributing } \\
\text { factors of illiteracy }\end{array}$} & Agree & $173(74.9 \%)$ & $84(71.2 \%)$ & $18(66.7 \%)$ & \multirow{3}{*}{$\begin{array}{c}x^{2}=6.373 \\
p=0.173\end{array}$} & \multirow[b]{3}{*}{$376(100 \%)$} \\
\hline & Disagree & $39(16.9 \%)$ & $30(25.4 \%)$ & $7(25.9 \%)$ & & \\
\hline & Uncertain & $19(8.2 \%)$ & $4(3.4 \%)$ & $2(7.4 \%)$ & & \\
\hline \multirow{3}{*}{$\begin{array}{l}\text { Open use of drugs } \\
\text { and selling are at } \\
\text { peak due } \\
\text { illiteracy }\end{array}$} & & $174(75.3 \%)$ & $79(66.9 \%)$ & $20(74.1 \%)$ & \multirow{3}{*}{$\begin{aligned} x^{2} & =5.444 \\
p & =0.245\end{aligned}$} & \multirow{3}{*}{$376(100 \%)$} \\
\hline & Disagree & $49(21.2 \%)$ & $36(30.5 \%)$ & $5(18.5 \%)$ & & \\
\hline & Uncertain & $8(3.5 \%)$ & $3(2.5 \%)$ & $2(7.4 \%)$ & & \\
\hline \multirow{3}{*}{$\begin{array}{lrr}\text { Illiteracy } & \text { leads } & \text { to } \\
\text { gambling } & \text { and } \\
\text { thievery } & & \end{array}$} & Agree & $172(74.5 \%)$ & $79(66.9 \%)$ & $18(66.7 \%)$ & \multirow{3}{*}{$\begin{aligned} x^{2} & =7.601 \\
p & =0.107\end{aligned}$} & \multirow{3}{*}{$376(100 \%)$} \\
\hline & Disagree & $57(24.7 \%)$ & $35(29.7 \%)$ & $7(25.9 \%)$ & & \\
\hline & Uncertain & $2(0.9 \%)$ & $4(3.4 \%)$ & $2(7.4 \%)$ & & \\
\hline \multirow{3}{*}{$\begin{array}{l}\text { Lack of awareness } \\
\text { about the crime is a } \\
\text { major problem in } \\
\text { society }\end{array}$} & Agree & $165(71.4 \%)$ & $70(59.3 \%)$ & $22(81.5 \%)$ & \multirow{3}{*}{$\begin{array}{l}x^{2} \\
=32.330 \\
p=0.000\end{array}$} & \multirow{3}{*}{$376(100 \%)$} \\
\hline & Disagree & $59(25.5 \%)$ & $24(20.3 \%)$ & $2(7.4 \%)$ & & \\
\hline & Uncertain & $7(3.0 \%)$ & $24(20.3 \%)$ & $3(11.1 \%)$ & & \\
\hline Lack of formal and & Agree & $192(83.1 \%)$ & $86(72.9 \%)$ & $18(66.7 \%)$ & $x^{2}=33.818$ & $376(100 \%)$ \\
\hline
\end{tabular}




\begin{tabular}{|c|c|c|c|c|c|}
\hline \multirow[b]{2}{*}{$\begin{array}{l}\text { informal education } \\
\text { is the responsible } \\
\text { factor in the } \\
\text { escalation of the } \\
\text { crime rate in the } \\
\text { area }\end{array}$} & Disagree & $36(15.6 \%)$ & $16(13.6 \%)$ & $3(11.1 \%)$ & \multirow[t]{2}{*}{$p=0.000$} \\
\hline & Uncertain & $2(0.9 \%)$ & $16(13.6 \%)$ & $6(22.2 \%)$ & \\
\hline
\end{tabular}

\section{DISCUSSION}

Criminal tendencies are increasing in Pakistan in the last two decades owing to a variety of reasons mostly because of a lack of social contract in rural areas and slums of Pakistan. Illiteracy compounds the issue of criminal behaviour as it is normalized in such communities where legal income opportunities for the less skilled and uneducated people are rare. Weapons demonstration, physical fights, and open use and sale of drugs becomes normal. The study finds strong association between a lack of education and higher rates of crime in the short and long run. Illiteracy does not only augment the crime rate, but both illiteracy and crime are the outcome of poverty in the study area. Illiterate people are supposed to be more probable to take part in violent crimes i.e. homicide, sexual assaults, arson, and robbery (Dalglish, 1982; Ullah \& Muhammad, 2020). The study further accredited that lack of awareness regarding crime is a foremost problem in the intensification of crime rate in the study area. This lack of awareness comes both from formal education and religious doctrines. Same is the case of a lukewarm attitude of families about their children education and general wellbeing. This lack of family oversight lead youth to antisocial activities, and they are likely to be living out on the streets, using drugs, and also prone to criminality (Castillo, 2007). Siblings relationship too has been found to have an effect on crime rates, particularly male members attitudes towards female family members. Eisner and Ghuneim (2013) advocated that attainment of education plays a significant role in the varying of people mindset and perception, particularly women rights were more reinforced and supported by the educated class. Other factors in criminal attitudes include a lack of self-control and impulsivity. Those who carry these traits often do things that they didn't plan, and they don't think before acting due to which often they commit a crime.

\section{CONCLUSIONS}

The notable conclusion of the study is reestablishing a positive relationship between lesser educational attainment and the higher crimes rate at a rural union council level. Major conclusions based on the study data include a) when young people start showing off weapons and indulge in physical brawls, more often than not, it has a lack of education as precursor; b) a lack of awareness about what amounts to criminal behavior due to lack of both formal and religious knowledge; c) poor socialization of children by their parents is a serious area to consider. Lastly the absence of implementation of law and order by law enforcement agencies further enhances crime in the study area.

\section{RECOMMENDATIONS}

- Massive social mobilization is required for young people to appreciate the fruits to peaceful coexistence and learn to differentiate between good and bad.

- Family as an institution requires deeper introspection in terms of socialization of children. Particularly the men attitude towards women needs to be challenged in conventional Pashtun families.

- Generally, it is established various research studies that poverty and intensification of criminality have positive and strong relationships. Skills trainings for the illiterate population and micro finance may go a long way in enabling youth to be productively engaged. Similarly, social protection schemes need to be expanded to households who are at risk of having family members prone to violence.

- Lastly the government needs to enhance its focus on providing quick and cheap justice to victims so that the perpetrators are not encouraged that they will walk out freely if they commit criminal acts.

\section{REFERENCES}


Becker, G. S. (1968). Crime and punishment: An economic approach. In The economic dimensions of crime (pp. 13-68): Springer.

Becker, G. S., \& Mulligan, C. B. (1997). The endogenous determination of time preference. The Quarterly Journal of Economics, 112(3), 729-758.

Bell, B., Costa, R., \& Machin, S. (2016). Crime, compulsory schooling laws and education. Economics of Education Review, 54, 214-226.

Brush, J. (2007). Does income inequality lead to more crime? A comparison of cross-sectional and time-series analyses of United States counties. Economics letters, 96(2), 264-268.

Buonanno, P. (2003). Identifying the effect of education on crime. Evidence from the Italian Regions.

Campaniello, N., Gray, R., \& Mastrobuoni, G. (2016). Returns to education in criminal organizations: Did going to college help Michael Corleone? Economics of Education Review, 54, 242-258.

Castillo, F. (2007). Lack of Education Contributes to Crime. Retrieved from.

Cerro, A. M., \& Meloni, O. (2000). Determinants of the crime rate in Argentina during the'90s. Estudios de economia, 27(2), 297-311.

Cullen, J. B., Jacob, B. A., \& Levitt, S. (2006). The effect of school choice on participants: Evidence from randomized lotteries. Econometrica, 74(5), 1191-1230.

Dalglish, C. L. (1982). Illiteracy and the offender: Huntington Publishers.

Deming, D. J. (2011). Better schools, less crime? The Quarterly Journal of Economics, 126(4), 20632115.

Dritsakis, N., \& Gkanas, A. (2009). The effect of socio-economic determinants on crime rates: An empirical research in the case of Greece with cointegration analysis. International Journal of Economic Sciences and Applied Research, 2(2).

Ehrlich, I. (1973). Participation in illegitimate activities: A theoretical and empirical investigation. Journal of political Economy, 81(3), 521-565.

Eisner, M., \& Ghuneim, L. (2013). Honor killing attitudes amongst adolescents in Amman, Jordan. Aggressive behavior, 39(5), 405-417.

Gillani, S. Y. M., Rehman, H. U., \& Gill, A. R. (2009). Unemployment, poverty, inflation and crime nexus: Cointegration and causality analysis of Pakistan. Pakistan Economic and Social Review, 79-98.

Groot, W., \& van den Brink, H. M. (2010). The effects of education on crime. Applied economics, 42(3), 279-289.

Hjalmarsson, R., Holmlund, H., \& Lindquist, M. J. (2015). The effect of education on criminal convictions and incarceration: Causal evidence from micro-data. The Economic Journal, 125(587), 1290-1326.

Khan, N., Ahmed, J., Nawaz, M., \& Zaman, K. (2015). The socio-economic determinants of crime in Pakistan: New evidence on an old debate. Arab Economic and Business Journal, 10(2), 7381.

Lancher, L. (2007). Education and crimes: A review of literature. University of western Ontario Dec.

Lochner, L. (2004). Education, work, and crime: A human capital approach. International Economic Review, 45(3), 811-843.

Lochner, L. (2011). Non-production benefits of education: Crime, health, and good citizenship.

Lochner, L., \& Moretti, E. (2004). The effect of education on crime: Evidence from prison inmates, arrests, and self-reports. American economic review, 94(1), 155-189.

McCall, R. B., \& Kagan, J. (1975). Fundamental statistics for psychology. Retrieved from

Nachmias, D., \& Nachmias, C. (1976). Research methods in the social sciences.

Nguyen, H. T. (2019). Do more educated neighbourhoods experience less property crime? Evidence from Indonesia. International Journal of Educational Development, 64, 27-37.

Rahman, M. L., \& Uddin, J. (2009). Dynamic relationship between stock prices and exchange rates: Evidence from three South Asian countries. International Business Research, 2(2), 167-174.

Rehman, A., Jingdong, L., \& Hussain, I. (2015). The province-wise literacy rate in Pakistan and its impact on the economy. Pacific Science Review B: Humanities and Social Sciences, 1(3), 140-144.

Sekaran, U. (2003). The Sampling Process of Research Methods for Business. In: USA: Hermitage Publishing Services. 
Smith, H. (1975). Strategies of social research. the methodological imagination. estrategias? de investigacion social. la imaginacion metodologica.

Tauchen, H., \& Witte, A. D. (1994). Work and crime: An exploration using panel data: National Bureau of Economic Research.

Ullah, A., \& Muhammad, N. (2020). Prevalence of mental health problems among youth involved in street crimes. Rawal Medical Journal, 45(4), 938-942.

Ward, S., \& Williams, J. (2015). Does juvenile delinquency reduce educational attainment? Journal of Empirical Legal Studies, 12(4), 716-756.

Webbink, D., Koning, P., Vujić, S., \& Martin, N. G. (2013). Why are criminals less educated than non-criminals? Evidence from a cohort of young Australian twins. The Journal of Law, Economics, \& Organization, 29(1), 115-144.

Witte, A. D., \& Tauchen, H. (1993). Work and crime: An exploration using panel data. In The economic dimensions of crime (pp. 176-191): Springer. 